\title{
Zinc and Copper Reduce Conjugative Transfer of Resistance Plasmids from Extended-Spectrum Beta-Lactamase-Producing Escherichia coli
}

\author{
May Linn Buberg, Ingun Lund Witsø, Trine Marie L’Abée-Lund, and Yngvild Wasteson
}

\begin{abstract}
The present work addresses the effect of excess levels of $\mathrm{ZnCl}_{2}$ and $\mathrm{CuSO}_{4}$ in the growth medium on the conjugative transfer of plasmids carrying the antibiotic resistance gene $b l a_{\mathrm{CMY}-2}$ from extended-spectrum betalactamase (ESBL)-producing Escherichia coli. Norwegian poultry are not treated prophylactically with antibiotics, but still, ESBL-producing E. coli are found in the chicken populations. Chickens receive higher amounts of $\mathrm{Zn}$ and $\mathrm{Cu}$ than their biological need, and several metals have been shown to act as drivers of antimicrobial resistance. In the present study, ESBL-producing E. coli strains collected from retail chicken meat were mated in broth containing various concentrations of $\mathrm{ZnCl}_{2}$ and $\mathrm{CuSO}_{4}$. Manual counting of transconjugants showed that $\mathrm{ZnCl}_{2}$ and $\mathrm{CuSO}_{4}$ reduced the conjugation frequency between E. coli strains in a concentration-dependent manner. Quantitative real-time PCR analyses showed that the presence of $\mathrm{ZnCl}_{2}$ and $\mathrm{CuSO}_{4}$ in the growth media reduced expression of the conjugation genes $\operatorname{traB}$ and nikB. By propagating monocultures over several generations, it was found that the bla $a_{\mathrm{CMY}-2}$ plasmids remained stable in the recipient strains. Together the results show that exposure of ESBL-producing E. coli to $\mathrm{Zn}$ and $\mathrm{Cu}$ reduce horizontal transfer of the $b l a_{\mathrm{CMY}-2}$ resistance plasmid by reducing expression of genes involved in conjugation in the plasmid donor strain.
\end{abstract}

Keywords: conjugation, CMY-2, antimicrobial resistance, poultry, zinc, copper

\section{Introduction}

$\mathbf{S}^{\mathrm{n}}$ PEAD OF ANTIMICROBIAL RESISTANCE (AMR) has become a significant threat against human and animal health. ${ }^{1}$ Parts of this resistance has its origin within the agriculture sector and dissemination of resistant bacteria from the food production chains may be one out of several routes by which consumers can be exposed to AMR bacteria. $^{2-6}$ In 2012, the NORM-VET monitoring program for AMR in the veterinary and food production sectors detected cephalosporin-resistant Escherichia coli in $43 \%$ of the Norwegian broiler flocks. ${ }^{7}$ In addition, $32 \%$ of $E$. coli from retail chicken meat were categorized as cephalosporin resistant, but even higher numbers were reported from Denmark and Sweden. ${ }^{8}$ The NORM-VET findings were surprising as the use of antimicrobial agents in the poultry production in Norway is limited, and among the lowest in Europe. ${ }^{7,9}$ In Norway, conjugative extended-spectrum betalactamase (ESBL)-encoding plasmids have frequently been discovered in bacteria isolated from broiler chicken, implicating that these animals are a potential reservoir for cephalosporin-resistant E. coli. ${ }^{10}$
Third and fourth generation cephalosporins have been defined as critically important antimicrobials by the World Health Organization. ${ }^{11}$ However, ESBL-producing bacteria have been isolated from a variety of animal species in different European countries, which could represent a major threat to public health. ${ }^{12-16}$ In 2015, the Norwegian Scientific Committee for Food and Environment concluded that "The probability of transfer of ESBL/AmpC-producing Enterobacteriaceae, quinolone-resistant E. coli, and their respective corresponding genes from live poultry and poultry meat is considered as non-negligible." 17 Exposure to ESBLproducing Enterobacteriaceae may result in consumers becoming carriers of resistant bacteria, if these bacteria establish themselves as part of the human gut microbiota. $3,18-20$ In situations where these bacteria cause disease, or spread their resistance genes to other pathogenic bacteria, their resistance characteristics may lead to treatment failure and increased mortality. ${ }^{21,22}$

Conjugation allows bacteria to spread genetic information across diverse bacterial phyla by the use of mobile genetic elements. $^{23}$ Inter- and intraspecies dissemination of resistance plasmids is the main mechanism of horizontal gene

Department of Paraclinical Sciences, Faculty of Veterinary Medicine, Norwegian University of Life Sciences, Oslo, Norway. 
transfer of AMR between bacteria and is mediated by the type IV secretion system (T4SS). ${ }^{24}$ The plasmid-located tra operon encodes the genes important for transport of the plasmid from the donor to the recipient cell. The TraB protein exhibit ATPase activity thought to provide energy for the assembly of the T4SS machinery and is known to play a major role in the conjugative transfer of plasmid DNA. ${ }^{25,26}$ Transfer of plasmid DNA is initiated and terminated at the origin of transfer, oriT. NikB encodes a relaxase, responsible for site- and strand-specific cleaving and rejoining of oriT at the nick site of the plasmid. ${ }^{27}$ Hansen et $a{ }^{28}{ }^{28}$ showed that horizontal transfer of plasmids is more important than clonal dissemination for transmission of bla $a_{\mathrm{CMY}-2}$ mediated cephalosporin resistance between animals and humans.

Mo et ll. $^{29}$ described two bla ${ }_{C M Y-2}$ encoding plasmids (pNVI1292/IncK and pNVI2798/IncI1), which were found in $E$. coli strains isolated from retail chicken meat in Norway. They further showed that the plasmids could spread to a variety of Enterobacteriaceae species by conjugation. These plasmids encode two plasmid stability systems, namely relBE/stbDE and pndAC, which presumably facilitate dissemination and stability of the $b l a_{C M Y-2}$ encoding plasmids. However, the importance of this stability system is not well studied.

Metals like $\mathrm{Zn}$ and $\mathrm{Cu}$ have antimicrobial effects; the bacterial toxicity of $\mathrm{Zn}$ may be due to the chemical affinity for thiol groups of biomolecules and $\mathrm{Cu}$ toxicity is based on production of hyperoxide radicals and interactions with cell membranes. ${ }^{30}$ Bacteria acquire resistance genes against antimicrobials and metals with antibacterial properties on mobile genetic elements. ${ }^{31}$ When two or more resistance genes are present on the same genetic element, or the same mechanism provides resistance against several substances, it may result in co-selection of genes conferring metal and antibiotic resistance. By these mechanisms, selection for resistance to zinc $(\mathrm{Zn})$, copper $(\mathrm{Cu})$, and other potentially toxic metals may act as drivers for spread of AMR. ${ }^{32,33}$ However, data on the required concentration and time exposure for this effect to occur is still lacking. ${ }^{34}$

$\mathrm{Zn}$ and $\mathrm{Cu}$ are important elements in the cellular metabolism; they allow many critical enzymes to function properly and are also essential for wound healing, protein synthesis, and maintaining the strength of the skin, blood vessels, and various tissues in the organism. ${ }^{35}$ Copper and zinc are routinely used as additives in animal feed in livestock farming, however, when animals receive feed containing larger amounts of $\mathrm{Zn}$ and $\mathrm{Cu}$ than what they biologically require the excess of metals are thereby released into the environment. ${ }^{36} \mathrm{Zn}$ and $\mathrm{Cu}$ are therefore commonly found in soil, water, plants, and in manure from various farm animals, including chicken. ${ }^{37}$ The occurrence of $\mathrm{Zn}$ and $\mathrm{Cu}$ may have beneficial fertilizing properties, as these are important trace elements for plants, but may also be of environmental concern when present in large quantities, affecting groundwater, surface water, and aquatic animals. $^{38-41}$

We hypothesize that excess levels of $\mathrm{Zn}$ and $\mathrm{Cu}$ promote transfer of resistance plasmids from ESBL-producing E. coli. The aim of our study was to assess the effect of $\mathrm{Zn}$ and $\mathrm{Cu}$ on conjugation of bla $a_{\mathrm{CMY}-2}$ carrying plasmids from ESBL-producing E. coli collected from retail chicken meat.

\section{Materials and Methods}

\section{Bacterial strains and growth media}

Two E. coli strains isolated from retail chicken meat were used as plasmid donors in the conjugation experiments; E. coli 2012-01-1292 (pNVI1292/IncK) and E. coli 201201-2798 (pNVI2798/IncI1), hereafter named E. coli 1292 (IncK) and E. coli 2798 (IncI1), respectively. The strains were collected through NORM-VET in 2012, and harbored the $b l a_{\mathrm{CMY}-2}$ gene, ${ }^{42}$ the most common plasmid-mediated AmpC-beta-lactamase in E. coli. ${ }^{43}$ Both strains have recently been whole genome sequenced (Mo et al.). ${ }^{42}$ The E. coli $\mathrm{DH} 5 \alpha$ strain, resistant to nalidixic acid $\left(\mathrm{Nal}^{\mathrm{R}}\right)$, was used as recipient. Both donors ferment lactose, while the recipient does not. The bacteria were cultured in LuriaBertani (LB) broth (Sigma-Aldrich, Germany) or Brain Heart Infusion broth (Sigma-Aldrich) throughout the whole study unless otherwise stated. $\mathrm{ZnCl}_{2}$ (Sigma-Aldrich) and $\mathrm{CuSO}_{4}$ (Merck, Germany) were used as sources of $\mathrm{Zn}$ and $\mathrm{Cu}$ throughout the whole study.

\section{In vivo and experimental concentrations of $\mathrm{Zn}$ and $\mathrm{Cu}$}

The NORM-VET collects AMR-bacteria from the cecum of chickens. To determine the in vivo concentrations of $\mathrm{Zn}$ and $\mathrm{Cu}$ in chicken cecum, ten 25-day-old chickens were collected from a commercial chicken farm in Norway. The chickens were euthanized, cecum-content collected, and analyzed for $\mathrm{Zn}$ and $\mathrm{Cu}$ content at Eurofins Food and Feed Testing Norway (Moss, Norway).

Experimental concentrations for $\mathrm{ZnCl}_{2}$ and $\mathrm{CuSO}_{4}$ to be used in the conjugation assays were chosen according to the two following criteria: (1) without exceeding the respective minimum inhibitory concentrations (MICs) and (2) reflect the range of concentrations found in vivo.

\section{Minimum inhibitory concentrations}

MICs for $\mathrm{ZnCl}_{2}$ and $\mathrm{CuSO}_{4}$ were determined for all strains by serial dilutions (Supplementary Table S1) in LBbroth. ${ }^{44}$ The concentrations tested ranged from $0.03 \mu \mathrm{g} / \mathrm{mL}$ to $3 \mathrm{mg} / \mathrm{mL}$ for $\mathrm{ZnCl}_{2}$ and $0.01 \mu \mathrm{g} / \mathrm{mL}$ to $1 \mathrm{mg} / \mathrm{mL}$ for $\mathrm{CuSO}_{4}$.

\section{Bacterial growth of donor and recipient strains}

Overnight cultures of each strain were diluted 1:1,000 in fresh LB-broth containing the selected experimental concentrations of $\mathrm{ZnCl}_{2}$ and $\mathrm{CuSO}_{4}$. A control without supplemented metals was included in each experiment. A volume of $200 \mu \mathrm{L}$ of each sample was transferred to a 96-well microtiter plate (Greiner; Sigma-Aldrich) and incubated at $37^{\circ} \mathrm{C}$ in Tecan platereader. The optical density $\left(\mathrm{OD}_{600}\right)$ was measured in the cultures every $10 \mathrm{~min}$ for $24 \mathrm{hr}$. Each experiment was performed in three biological replicates, with three replicates of each sample.

\section{Conjugation study}

Conjugation experiments were conducted in LB-broth according to Sunde and Sorum, ${ }^{45}$ with minor modifications. Briefly, the donor and recipient strains were grown overnight in LB-broth at $37^{\circ} \mathrm{C}$ and subsequently diluted to an $\mathrm{OD}_{600}$ equivalent to a McFarland standard no. $1(\sim 3 \mathrm{E}+8$ 
bacteria/mL). ${ }^{46}$ A volume of $500 \mu \mathrm{L}$ of the recipient strain culture and $10 \mu \mathrm{L}$ of the donor strain culture was mixed in $4 \mathrm{~mL}$ LB-broth containing the selected experimental concentrations of $\mathrm{ZnCl}_{2}$ or $\mathrm{CuSO}_{4}$, respectively, including a control without supplements. All cultures were incubated for $4 \mathrm{hr}$ at $37^{\circ} \mathrm{C}$. LB-broth supplemented with $\mathrm{Zn}$ or $\mathrm{Cu}$ were prepared 1 day before the experiment and incubated at $37^{\circ} \mathrm{C}$ overnight under agitation to prevent precipitation of the added metal. Dilutions of each mating culture were plated on Mueller-Hinton agar plates (Sigma-Aldrich) supplemented with $20 \mathrm{mg} / \mathrm{L}$ nalidixic acid and/or $0.5 \mathrm{mg} / \mathrm{L}$ cefotaxime, and incubated for 24 and $48 \mathrm{hr}$ at $37^{\circ} \mathrm{C}$. To quantify the conjugation and to test for toxic effects of the metals on the donor and recipient strains individually, we plated the mating cultures on donor-, recipient-, and transconjugant selective plates. The conjugation frequency was determined by manual counting of colony forming units (CFU) and dividing the number of transconjugants with the number of recipients.

Representative colonies from each transconjugantselective plate was plated on bromothymol lactose blue agar (Sigma-Aldrich) to distinguish transconjugants from spontaneously mutated donors. In addition to different abilities to ferment lactose, the transconjugants and mutated donors are distinguishable by colony morphology. PCR analysis of bacterial colonies was conducted to confirm that the transconjugants harbored the $b l a_{\mathrm{CMY}-2}$ gene. $^{47}$

\section{Plasmid stability}

The transconjugants from the conjugation assay (DH5 $\alpha$ with pNVI1292/IncK or pNVI2798/IncI1) were propagated by serial transfers as previously described. ${ }^{48,49}$ with minor modifications. Briefly, $10 \mu \mathrm{L}$ of stationary phase culture was transferred into $990 \mu \mathrm{L}$ of fresh LB-broth supplemented with $0.05 \mathrm{mg} / \mathrm{mL} \mathrm{ZnCl}_{2}$ or $0.01 \mathrm{mg} / \mathrm{mL} \mathrm{CuSO}_{4}$ every $12 \mathrm{hr}$ for 5 days, corresponding to $\sim 300$ generations. Cultures in LBbroth without metal supplements were used as controls. The bacteria were grown at $37^{\circ} \mathrm{C}$ under agitation $(180 \mathrm{rpm})$. To confirm the presence or absence of plasmids pNVI1292/ IncK and pNVI2798/IncI1, serial diluted samples from each transfer were plated on Mueller-Hinton agar plates with or without antibiotics $(20 \mathrm{mg} / \mathrm{mL}$ nalidixic acid and $0.5 \mathrm{mg} / \mathrm{mL}$ cefotaxime). Plates without antibiotics were incubated at $37^{\circ} \mathrm{C}$ for $24 \mathrm{hr}$ and plates containing antibiotics were incubated for $48 \mathrm{hr}$. The number of CFU was counted manually. The presence of the $b l a_{C M Y-2}$ plasmid was confirmed by colony PCR. ${ }^{47}$

\section{Sample preparation, RNA isolation, and quantitative $P C R$}

The transcriptional analysis of genes involved in conjugation, nikB and traB, was performed in E. coli 1292 (IncK). An overnight culture was inoculated in fresh LB-broth with $\mathrm{ZnCl}_{2}$ or $\mathrm{CuSO}_{4}$. Bacteria cultured in plain LB media were used for comparison. The samples were incubated for $4 \mathrm{hr}$ at $37^{\circ} \mathrm{C}$. Total RNA was isolated from harvested E. coli using PureLink RNA Mini Kit (Life technologies, Carlsbad, CA) according to the manufacturer's protocol. On-column PureLink DNAse (Life technologies) treatment was performed according to the protocol. An amount of $100 \mathrm{ng}$ of total RNA was used to synthesize cDNA using High Capacity cDNA Reverse Transcriptase kit (Applied Biosystems, California, CA) according to the manufacturer's protocol. Primers were designed by Primer Express software, and the sequences are listed in Table 1. A standard curve using serial dilution of DNA from E. coli 1292 was made to calculate PCR efficiency for each primer pair. Real time reactions were performed using Power SYBR Green PCR Master Mix (Life Technologies) and real time amplification was carried out using Step One Real Time PCR system (Applied Biosystems). The data were collected and analyzed by normalization against the endogenous control gene rpoA using StepOne Software v2.3.

\section{Statistical analysis}

All experiments were performed as at least three independent experiments, with three technical replicates. As data were not normally distributed, we used a nonparametric regression through the quantile regression technique in Stata (Stata MP/16 for Windows), to evaluate the effect of $\mathrm{ZnCl}_{2}$ and $\mathrm{CuSO}_{4}$ levels on the experiments. We adjusted for the impact of strain and biological replicate. Results were

Table 1. Primers Used in This Study for Quantitative Polymerase Chain Reaction for Evaluation of EXPRESSION OF GENES InVOLVED In CONJUGation

\begin{tabular}{|c|c|c|c|c|c|}
\hline \multirow[b]{2}{*}{ Gene } & \multicolumn{2}{|c|}{ Primer sequences } & \multirow[b]{2}{*}{ Slope } & \multirow[b]{2}{*}{$\% E f f^{b}$} & \multirow[b]{2}{*}{ Gene description $^{\mathrm{c}}$} \\
\hline & Forward $\left(5^{\prime}-3^{\prime}\right)$ & Reverse $\left(5^{\prime}-3^{\prime}\right)$ & & & \\
\hline$n i k B$ & CGCCTGATAATGGCTGCTTT & CGCTGTTTTGCGCACAATA & -3.44 & 95.05 & $\begin{array}{l}\text { Conjugal transfer } \\
\text { relaxase protein } \\
\text { NikB }\end{array}$ \\
\hline rpoA & GGCACAATCGATCCTGAAGAG & TTCCAGTTGTTCAGCCAGAATG & -3.37 & 97.85 & $\begin{array}{l}\text { DNA-directed RNA } \\
\text { polymerase, } \\
\text { alpha subunit }\end{array}$ \\
\hline $\operatorname{traB}$ & GGCAAAAACCGCGAACAT & TCCAGGGAAGGACGTGTTG & -3.4 & 96.75 & $\begin{array}{l}\text { Type IV secretion/ } \\
\text { conjugal transfer } \\
\text { ATPase, VirB4 } \\
\text { family }\end{array}$ \\
\hline
\end{tabular}

\footnotetext{
${ }^{\text {a }}$ The slope was calculated from the regression line in the standard curve.

${ }^{\mathrm{b}}$ The efficiency was calculated using the slope of the regression line in the standard curve.

${ }^{\mathrm{c}}$ According to UniProt Database.
} 
reported as coefficients with corresponding $p$-values when compared to the control. One-way ANOVA was used in the comparison of differences between samples with $\mathrm{Zn}$ and $\mathrm{Cu}$ and the control samples in the plasmid stability experiment and the analysis of gene expression. The level of statistical significance was set to $p<0.05$.

\section{Results}

\section{Selected $\mathrm{Zn}$ and Cu concentrations}

The poultry feed contained $100 \mathrm{mg} / \mathrm{kg} \mathrm{Zn}$ and $15 \mathrm{mg} / \mathrm{kg}$ $\mathrm{Cu}$, and the results from the poultry cecum-content ranged from 8.52 to $83.5 \mathrm{mg} / \mathrm{kg} \mathrm{Cu}$ and 71.9 to $225 \mathrm{mg} / \mathrm{kg} \mathrm{Zn}$. MIC data for E. coli 1292 (IncK) and E. coli 2798 (IncI1) is shown in Table 2. Thus, the experimental concentrations were selected as follows: $0.05,0.125$, and $0.2 \mathrm{mg} / \mathrm{mL}$ for $\mathrm{ZnCl}_{2}$, and $0.01,0.255$ and $0.5 \mathrm{mg} / \mathrm{mL}$ for $\mathrm{CuSO}_{4}$. This is equivalent to $0.024,0.06$, and $0.096 \mathrm{mg} / \mathrm{mL}$ elemental $\mathrm{Zn}$ and $0.0039,0.101$, and $0.199 \mathrm{mg} / \mathrm{mL}$ elemental $\mathrm{Cu}$.

\section{Bacterial growth}

Growth curves for the donor and recipient strains are shown in Fig. 1. The lowest concentration of $\mathrm{ZnCl}_{2}$ did not appear to have any effect on planktonic growth, while the two highest concentrations displayed a delayed growth rate $(0.125$ and $0.2 \mathrm{mg} / \mathrm{mL}$ ). None of the concentrations of $\mathrm{CuSO}_{4}$ appear to have any effect on the planktonic growth of the strains. The two donor strains E. coli 1292 (IncK) and E. coli 2798 (IncI1) showed higher growth rates compared to the recipient $E$. coli DH5 $\alpha$ strain. Growth rates are provided in the supplementary material (Supplementary Table S2).

\section{Conjugation study}

The conjugation frequency was first determined in a pilot study where samples were taken after 4 and $24 \mathrm{hr}$ of mating. No difference in the conjugation frequency was observed between the two time points (data not shown). Therefore, $4 \mathrm{hr}$ was chosen for further conjugation and transcriptional studies. The mating cultures were plated on donor-, recipient-, and transconjugant selective plates to calculate the conjugation frequency (Table 3 ) and to evaluate any inhibiting effect of the metals in the mating cultures. Neither the donors nor the recipient showed any reduction in $\mathrm{CFU}$ compared to the control (data not shown).

As shown in Fig. 2 the effect of increasing levels of $\mathrm{ZnCl}_{2}$ and $\mathrm{CuSO}_{4}$ on conjugation were clear. These findings were supported by the nonparametric regression analysis, where strong effects of $\mathrm{Zn}$ and $\mathrm{Cu}$ levels were found $(p<0.001)$. There was no effect of the donor strains on the number of recipients in the conjugation experiments in $\mathrm{ZnCl}_{2}(p=$

Table 2. Determined Minimum Inhibitory

Concentrations of $\mathrm{ZnCL}_{2} \mathrm{AND} \mathrm{CuSO}_{4}$ FOR DONOR AND RECIPIENT STRAINS

\begin{tabular}{|c|c|c|c|}
\hline $\begin{array}{l}\text { Metal/ } \\
\text { strain }\end{array}$ & $\begin{array}{c}\text { E. coli } \\
1292 \text { (IncK), } \\
m g / m L\end{array}$ & $\begin{array}{c}\text { E. coli } \\
2798 \text { (IncII), } \\
m g / m L\end{array}$ & $\begin{array}{l}\text { E. coli } \\
D H 5 \alpha, \\
m g / m L\end{array}$ \\
\hline $\mathrm{ZnCl}_{2}$ & 0.4 & 0.4 & 0.3 \\
\hline $\mathrm{CuSO}_{4}$ & 0.9 & 1 & 0.75 \\
\hline
\end{tabular}
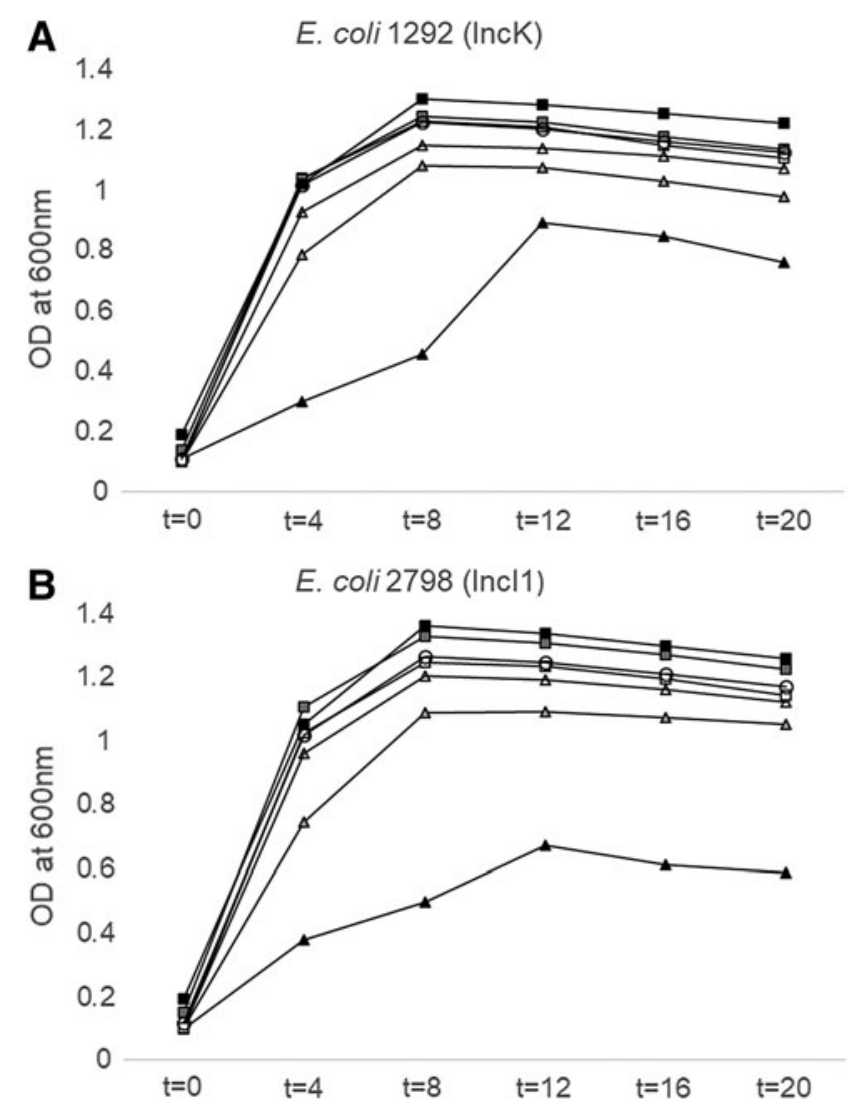

C ${ }_{1.4}$ E. coli DH5a

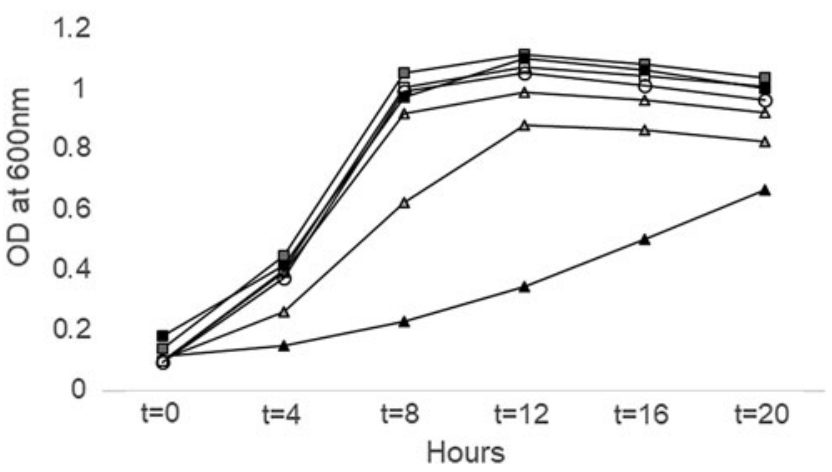

FIG. 1. Growth curves. (A) Escherichia coli 1292 (IncK), (B) E. coli 2798 (IncI1), (C) E. coli DH5 $\alpha$ ( $\triangle$ ) $0.05 \mathrm{mg} / \mathrm{mL}$

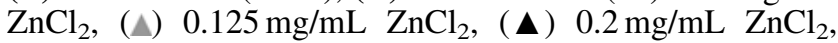

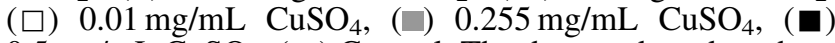
$0.5 \mathrm{mg} / \mathrm{mL} \mathrm{CuSO}_{4}$, ( $\left.\bigcirc\right)$ Control. The data are based on three biological replicates with three technical replicates each.

0.31) and $\mathrm{CuSO}_{4}(p=0.55)$, which confirms that the recipients are not outcompeted by the donors (Supplementary Fig. S1). No statistical effect of replicate could be observed in the data. Our results show that conjugation of the IncK plasmid was reduced by more than $98 \%$ at all concentrations of $\mathrm{Zn}$ tested compared to the control. This was also observed for the two highest concentrations of $\mathrm{CuSO}_{4}$ while $0.01 \mathrm{mg} / \mathrm{mL}$ $\mathrm{CuSO}_{4}$ gave a $90 \%$ reduction of conjugation for the $\mathrm{IncK}$ plasmid. At the two highest concentrations of $\mathrm{Zn}$ and $\mathrm{Cu}$ there was a more than $90 \%$ reduced conjugation of the IncI1 plasmid, while the lowest concentrations of $\mathrm{Zn}$ and $\mathrm{Cu}$ gave 
Table 3. Conjugation Frequencies in Response to Different Concentrations of $\mathrm{ZNCL}_{2} \mathrm{AND}_{\mathrm{CuSO}}$

\begin{tabular}{llllc}
\hline Strain & Additive & $m g / m L$ & $\begin{array}{l}\text { Conjugation } \\
\text { frequency }^{\mathrm{a}}\end{array}$ & \multicolumn{1}{c}{$S D+/-$} \\
\hline $\begin{array}{l}\text { E. coli 2798 } \\
\text { (IncI1) }\end{array}$ & $\mathrm{CuSO}_{4}$ & 0.01 & $1.26 \mathrm{E}-04$ & $1.03 \mathrm{E}-04$ \\
& & 0.255 & $3.95 \mathrm{E}-06$ & $9.12 \mathrm{E}-06$ \\
& $\mathrm{ZnCl}_{2}$ & 0.5 & NTD & $0.00 \mathrm{E}+00$ \\
& & 0.125 & $9.31 \mathrm{E}-05$ & $6.00 \mathrm{E}-05$ \\
& & 0.2 & NTD & $6.85 \mathrm{E}-06$ \\
& Control & 0 & $2.04 \mathrm{E}-04$ & $0.00 \mathrm{E}+00$ \\
$\begin{array}{l}\text { E. coli } 1292 \\
\text { (IncK) }\end{array}$ & $\mathrm{CuSO}_{4}$ & 0.01 & $3.37 \mathrm{E}-05$ & $4.57 \mathrm{E}-05$ \\
& & 0.255 & $2.37 \mathrm{E}-06$ & $2.28 \mathrm{E}-06$ \\
& $\mathrm{ZnCl}_{2}$ & 0.5 & NTD & $0.00 \mathrm{E}+00$ \\
& & 0.05 & $1.04 \mathrm{E}-06$ & $1.35 \mathrm{E}-06$ \\
& & 0.2 & NTD & $0.00 \mathrm{E}+00$ \\
& $\mathrm{Control}^{2}$ & 0 & $9.21 \mathrm{E}-05$ & $0.00 \mathrm{E}+00$ \\
& & & $5.31 \mathrm{E}-05$
\end{tabular}

${ }^{\mathrm{a}}$ Conjugation frequencies were calculated as the mean number of transconjugants divided by the mean number of recipients from all replicates, for each combination.

NTD, no transfer detected (no colonies detected) on transconjugant selective plate.

a reduction of $58 \%$ and $41 \%$, respectively. A representative selection of colonies was picked for further confirmation and all of them were confirmed PCR-positive for the $b l a_{C M Y-}$ 2 gene. Furthermore, all tested transconjugants gave a negative result on the bromomethyl lactose agar, confirming the recipient phenotype.

\section{Plasmid stability}

Both plasmids carry genes encoding stability systems (relBE/stbDE and $p n d A C$ ). We wanted to investigate whether these stability systems promote plasmid maintenance, and if $\mathrm{Zn}$ and $\mathrm{Cu}$ had any impact on the stability of the plasmids. By propagating the transconjugants in monocultures for $\sim 300$ generations and calculate $\mathrm{CFU}$ after plating on transconjugant selective plates, we could show that both plasmids were maintained within the transconjugants (Supplementary Fig. S2). Furthermore, the results showed that there was no difference in plasmid stability between the IncK- and the IncI1 plasmid and that subinhibitory concentrations of $\mathrm{ZnCl}_{2}$ and $\mathrm{CuSO}_{4}$ did not have any influence on the maintenance of the plasmids $(p<0.05)$.

\section{Effect of $\mathrm{Zn}$ and $\mathrm{Cu}$ on expression of conjugative-related genes}

Qualitative PCR analysis showed that genes involved in transfer of the IncK plasmid had a significantly reduced expression following exposure to $0.05 \mathrm{mg} / \mathrm{mL} \mathrm{ZnCl}_{2}$ or $0.01 \mathrm{mg} / \mathrm{mL} \mathrm{CuSO}{ }_{4}$ compared to the control $(p<0.05)$ (Fig. 3). Specifically, the expression of $\operatorname{traB}$ was reduced by $87 \%$ and $92 \%$ in the samples with $\mathrm{ZnCl}_{2}$ and $\mathrm{CuSO}_{4}$ compared to the control without $\mathrm{ZnCl}_{2}$ or $\mathrm{CuSO}_{4}$. The expression of $n i k B$ was reduced by $97 \%$ and $96 \%$ in response to $\mathrm{ZnCl}_{2}$ and $\mathrm{CuSO}_{4}$ compared to the control.

\section{Discussion}

Conjugation is a complex mechanism that allows bacteria to spread genes encoding beneficial traits that will increase
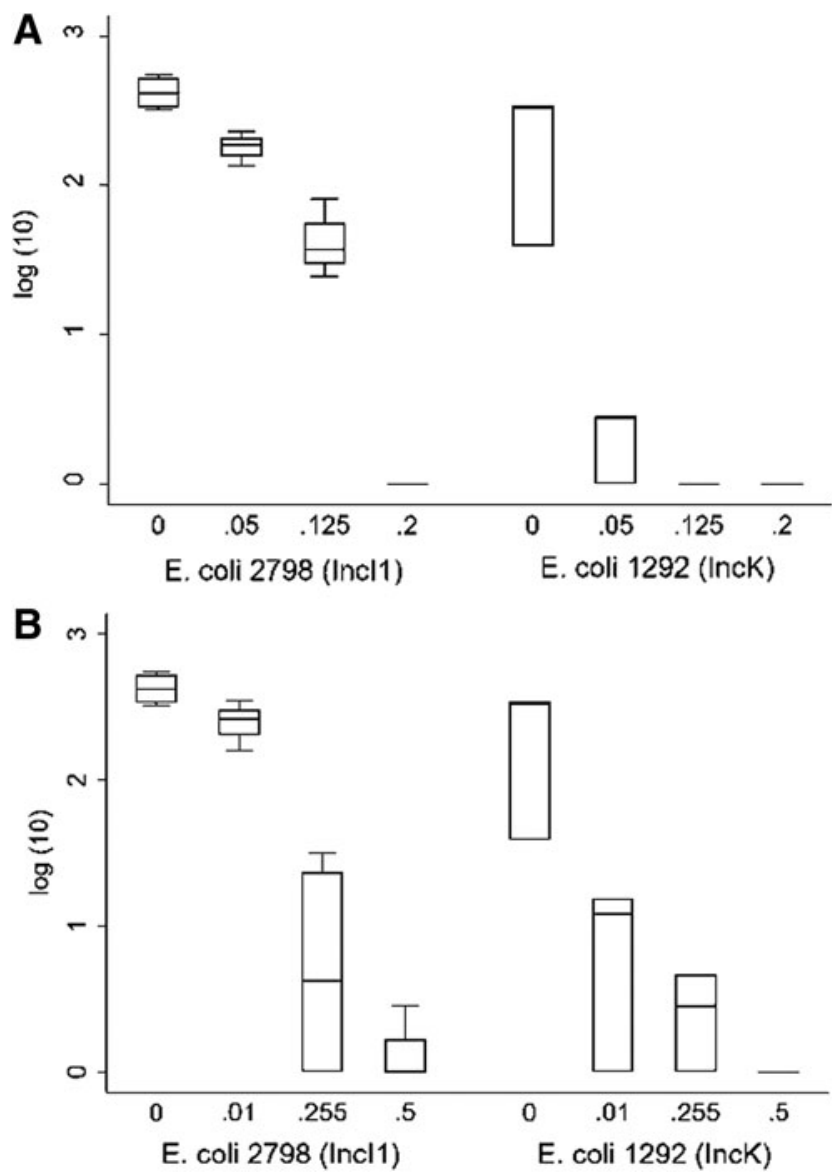

FIG. 2. Distribution of transconjugants demonstrating a dose-dependent reduction of transconjugants in the presence of $\mathrm{ZnCl}_{2}$ (A) and $\mathrm{CuSO}_{4}(\mathbf{B})$. Concentrations are provided in $\mathrm{mg} / \mathrm{mL}$ for $\mathrm{ZnCl}_{2}$ and $\mathrm{CuSO}_{4}$. The horizontal line within the box represents the median. Boxes represent $50 \%$ of the data and the whiskers, highest and lowest values, while dots represent outliers. The data are based on four biological replicates with three technical replicates each.

bacterial survival. A previous study has shown that the two plasmids included in this study are inter- and intra-species transferable at different conditions, indicating that they may contribute to the maintenance of antibiotic-resistant genes in the environment. ${ }^{29}$ In contrast to earlier studies, which show

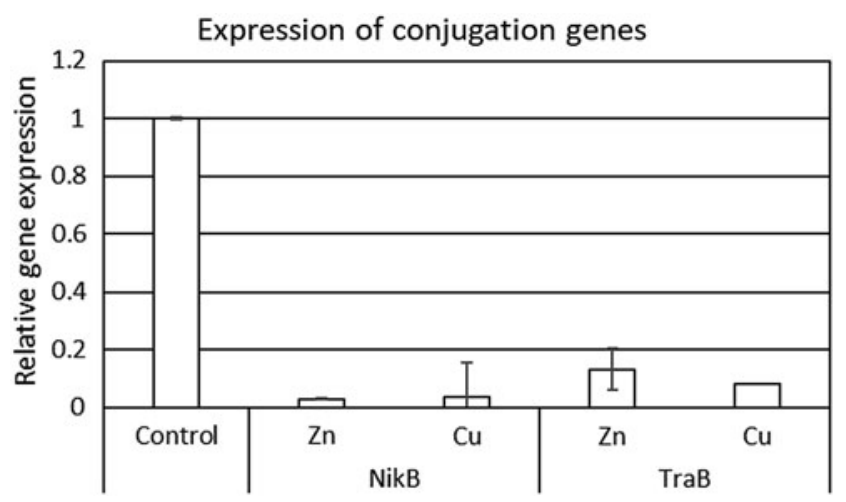

FIG. 3. Expression of genes involved in conjugation in Escherichia coli 1292 (IncK) in response to $\mathrm{ZnCl}_{2}$ and $\mathrm{CuSO}_{4}$. The data are presented as mean values $\pm \operatorname{SD}(n=6)$. 
that $\mathrm{Zn}$ and $\mathrm{Cu}$ are associated with increased conjugation, ${ }^{50-53}$ we found that $\mathrm{Zn}$ and $\mathrm{Cu}$ reduced the conjugation frequency between $E$. coli strains in a concentrationdependent manner. There was also no difference in the number of colonies on the donor- and recipient-selective plates from the mating cultures, which confirms that $\mathrm{Zn}$ and $\mathrm{Cu}$ does not affect growth of donor- or recipient strains. Toxic effects of the metals can therefore not explain the observed reduction in conjugation frequencies. A pilot study was performed at both 4 and $24 \mathrm{hr}$ of mating (data not shown). No difference in conjugation rate was observed between the two time points, which is consistent with a previous report by Mo et al. $^{29}$ Altogether, this justifies our choice of using the $4 \mathrm{hr}$ time point in the mating experiments. The growth curves showed that the recipient strain grew slightly slower than the donor strain, however, this was compensated for by using larger amounts of recipient cells in the conjugation experiments.

The plasmids used in this study did not contain any known $\mathrm{Zn}$ or $\mathrm{Cu}$ resistance genes, ${ }^{42}$ which rules out coselective mechanisms. Our results are consistent with a recent study, which showed that metal stress $(\mathrm{Zn}$ and $\mathrm{Cu}$ included) decreased plasmid transfer frequencies to bacterial communities independent of metal-resistance. ${ }^{54}$ Suzuki et al. $^{55}$ also showed a reduction in horizontal transfer of the tetracycline resistance gene tet $(\mathrm{M})$ in response to $\mathrm{Zn}$ and $\mathrm{Cu}$ exposure. Reduced plasmid transfer in response to metal stress could be a consequence of changes in metabolic status, decrease in plasmid replication, activation of the SOSresponse, or a combination of different mechanisms. ${ }^{56-58}$ This study also showed that both the IncK and IncI1 plasmids remained stable in their host throughout several generations, independent of presence of $\mathrm{Zn}$ or $\mathrm{Cu}$.

The molecular mechanisms of heavy metals on conjugative transfer of resistance genes, with exception of coselective mechanisms, have rarely been investigated. ${ }^{59}$ To understand the effect of $\mathrm{Zn}$ and $\mathrm{Cu}$ on conjugation in our study, we performed a real-time transcriptional analysis that showed a reduction in expression of conjugation-associated genes in response to subinhibitory concentrations of $\mathrm{Zn}$ and $\mathrm{Cu}$. However, our findings contrast the report by Zhang et al. ${ }^{52}$ who found that different concentrations of heavy metals increased conjugation and upregulated the expression of genes involved in conjugation of plasmids. Strain background, concentrations of the metals, and experimental conditions might explain the contradictory results.

Conjugative transfer of plasmids are controlled by a wide range of genes. ${ }^{60} \mathrm{~A}$ failure to form a functional relaxosome, mediated by the NikB protein, can result in an incapability of the plasmid to mobilize. ${ }^{61}$ Our results from the transcriptional analysis could therefore indicate that the reduced expression of nikB in response to $\mathrm{Zn}$ and $\mathrm{Cu}$ could lead to a dysfunctional relaxosome, and the incapability of the plasmid to transfer from the donor to the recipient strain. The expression of the $t r a B$ gene involved in plasmid transfer was also significantly reduced, which indicates that metals disturb the function of the conjugation machinery.

Our goal was to use concentrations of $\mathrm{Zn}$ and $\mathrm{Cu}$ that mimic the conditions found in the chicken intestines as closely as possible. We focused on the effect of heavy metals on the plasmid-encoded genes by using an experimental setup that excluded the effect of co-selection.
However, we cannot exclude that $\mathrm{Zn}$ and $\mathrm{Cu}$ interfere with expression of chromosomal genes or genes located in the recipient strain. The effect of $\mathrm{Zn}$ and $\mathrm{Cu}$ on the SOSresponse may be of future interest, in addition to investigate the combined effect of $\mathrm{Zn}$ and $\mathrm{Cu}$ on conjugation. The expression of other conjugational genes needs to be studied to learn more about how metals interfere with conjugation at a transcriptional level. It would also be beneficial to study horizontal gene transfer in more complex models than the ones used in the present study; preferable models that to a larger degree resembles the "real life" conditions in the chicken intestinal environment. Nevertheless, our results indicate altogether that $\mathrm{Zn}$ and $\mathrm{Cu}$ interfere with genes involved in conjugation, and thereby decrease the frequency of conjugational transfer of plasmids between E. coli.

\section{Acknowledgments}

Are Holmen is acknowledged for providing chicken, Eystein Skjerve for statistical help. Kristin O'Sullivan, Helge Hansen, Toril Lindbäck, and Solveig Sølverød Mo for technical assistance, and Marina E. Aspholm for language editing and proofreading.

\section{Disclosure Statement}

No competing financial interests exist.

\section{Funding Information}

This work was funded by The Research Council of Norway, grant no. 250212. The funders had no role in study design, data collection and interpretation, or the decision to submit the work for publication.

\section{Supplementary Material}

Supplementary Table S1

Supplementary Table S2

Supplementary Figure S1

Supplementary Figure S2

\section{References}

1. French, G.L. 2010. The continuing crisis in antibiotic resistance. Int. J. Antimicrob. Agents. 36(Suppl 3):S3-S7.

2. Nelson, J.M., T.M. Chiller, J.H. Powers, and F.J. Angulo. 2007. Fluoroquinolone-resistant Campylobacter species and the withdrawal of fluoroquinolones from use in poultry: a public health success story. Clin. Infect. Dis. 44:977-980.

3. Leverstein-van Hall, M.A., C.M. Dierikx, J. Cohen Stuart, G.M. Voets, M.P. van den Munckhof, A. van EssenZandbergen, T. Platteel, A.C. Fluit, N. van de SandeBruinsma, J. Scharinga, M.J. Bonten, and D.J. Mevius. 2011. Dutch patients, retail chicken meat and poultry share the same ESBL genes, plasmids and strains. Clin. Microbiol. Infect. 17:873-880.

4. Muzslay, M., G. Moore, N. Alhussaini, and A.P. Wilson. 2017. ESBL-producing Gram-negative organisms in the healthcare environment as a source of genetic material for resistance in human infections. J. Hosp. Infect. 95:59-64.

5. Meyer, E., P. Gastmeier, A. Kola, and F. Schwab. 2012. Pet animals and foreign travel are risk factors for colonisation with extended-spectrum beta-lactamase-producing Escherichia coli. Infection 40:685-687. 
6. von Wintersdorff, C.J.H., J. Penders, E.E. Stobberingh, A.M.L.O. Lashof, C.J.P.A. Hoebe, P.H.M. Savelkoul, and P.F.G. Wolffs. 2014. High rates of antimicrobial drug resistance gene acquisition after international travel, The Netherlands. Emerg. Infect. Dis. 20:649-657.

7. NORM/NORM-VET. 2012. Usage of Antimicrobial Agents and Occurrence of Antimicrobial Resistance in Norway.

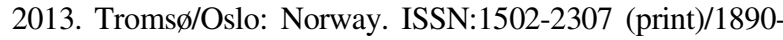
9965 (electronic).

8. Borjesson, S., M. Egervarn, M. Lindblad, and S. Englund. 2013. Frequent occurrence of extended-spectrum betalactamase- and transferable ampc beta-lactamaseproducing Escherichia coli on domestic chicken meat in Sweden. Appl. Environ. Microbiol. 79:2463-2466.

9. Garcia-Migura, L., R.S. Hendriksen, L. Fraile, and F.M. Aarestrup. 2014. Antimicrobial resistance of zoonotic and commensal bacteria in Europe: the missing link between consumption and resistance in veterinary medicine. Vet. Microbiol. 170:1-9.

10. Mo, S.S., M. Norstrom, J.S. Slettemeas, A. Lovland, A.M. Urdahl, and M. Sunde. 2014. Emergence of AmpCproducing Escherichia coli in the broiler production chain in a country with a low antimicrobial usage profile. Vet. Microbiol. 171:315-320.

11. WHO. 2014. Antimicrobial resistance: global report on surveillance 2014. World Health Organization, Geneva.

12. Liebana, E., A. Carattoli, T.M. Coque, H. Hasman, A.P. Magiorakos, D. Mevius, L. Peixe, L. Poirel, G. SchuepbachRegula, K. Torneke, J. Torren-Edo, C. Torres, and J. Threlfall. 2013. Public health risks of enterobacterial isolates producing extended-spectrum beta-lactamases or AmpC beta-lactamases in food and food-producing animals: an EU perspective of epidemiology, analytical methods, risk factors, and control options. Clin. Infect. Dis. 56:1030 1037.

13. Carattoli, A., S. Lovari, A. Franco, G. Cordaro, P. Di Matteo, and A. Battisti. 2005. Extended-spectrum $\beta$ lactamases in Escherichia coli isolated from dogs and cats in Rome, Italy, from 2001 to 2003. Antimicrob. Agents Chemother. 49:833-835.

14. Hasman, H., D. Mevius, K. Veldman, I. Olesen, and F.M. Aarestrup. 2005. Beta-lactamases among extendedspectrum beta-lactamase (ESBL)-resistant Salmonella from poultry, poultry products and human patients in The Netherlands. J. Antimicrob. Chemother. 56:115-121.

15. Costa, D., P. Poeta, Y. Sáenz, L. Vinué, B. Rojo-Bezares, A. Jouini, M. Zarazaga, J. Rodrigues, and C. Torres. 2006. Detection of Escherichia coli harbouring extendedspectrum $\beta$-lactamases of the CTX-M, TEM and SHV classes in faecal samples of wild animals in Portugal. J. Antimicrob. Chemother. 58:1311-1312.

16. Vo, A.T., E. van Duijkeren, A.C. Fluit, and W. Gaastra. 2007. Characteristics of extended-spectrum cephalosporinresistant Escherichia coli and Klebsiella pneumoniae isolates from horses. Vet. Microbiol. 124:248-255.

17. VKM. 2015. Assessment of antimicrobial resistance in the food chains in Norway. Scientific Opinion of the Panel on microbiological hazards of the Norwegian Scientific Committee for Food Safety. Oslo: Norway. ISBN: 978-828259-184-3.

18. Sharp, H., L. Valentin, J. Fischer, B. Guerra, B. Appel, and A. Kasbohrer. 2014. Estimation of the transfer of ESBLproducing Escherichia coli to humans in Germany. Berl. Munch. Tierarztl. Wochenschr. 127:464-477.
19. Blanc, V., R. Mesa, M. Saco, S. Lavilla, G. Prats, E. Miro, F. Navarro, P. Cortes, and M. Llagostera. 2006. ESBL- and plasmidic class $\mathrm{C}$ beta-lactamase-producing $E$. coli strains isolated from poultry, pig and rabbit farms. Vet. Microbiol. 118:299-304.

20. Carattoli, A. 2008. Animal reservoirs for extended spectrum beta-lactamase producers. Clin. Microbiol. Infect. 14(Suppl 1):117-123.

21. Schwaber, M.J., and Y. Carmeli. 2007. Mortality and delay in effective therapy associated with extended-spectrum beta-lactamase production in Enterobacteriaceae bacteraemia: a systematic review and meta-analysis. J. Antimicrob. Chemother. 60:913-920.

22. Vincent, J.L., J. Rello, J. Marshall, E. Silva, A. Anzueto, C.D. Martin, R. Moreno, J. Lipman, C. Gomersall, Y. Sakr, and K. Reinhart. 2009. International study of the prevalence and outcomes of infection in intensive care units. JAMA 302:2323-2329.

23. Klümper, U., L. Riber, A. Dechesne, A. Sannazzarro, L.H. Hansen, S.J. Sørensen, and B.F. Smets. 2014. Broad host range plasmids can invade an unexpectedly diverse fraction of a soil bacterial community. ISME J. 9:934.

24. Ilangovan, A., S. Connery, and G. Waksman. 2015. Structural biology of the Gram-negative bacterial conjugation systems. Trends. Microbiol. 23:301-310.

25. Zechner, E.L., S. Lang, and J.F. Schildbach. 2012. Assembly and mechanisms of bacterial type IV secretion machines. Philos. Trans. R Soc. Lond. B. Biol. Sci. 367:1073-1087.

26. Durand, E., C. Oomen, and G. Waksman. 2010. Biochemical dissection of the ATPase TraB, the VirB4 homologue of the Escherichia coli pKM101 conjugation machinery. J. Bacteriol. 192:2315-2323.

27. Furuya, N., and T. Komano. 2003. NikAB- or NikBdependent intracellular recombination between tandemly repeated oriT sequences of plasmid R64 in plasmid or single-stranded phage vectors. J. Bacteriol. 185:3871-3877.

28. Hansen, K.H., V. Bortolaia, C.A. Nielsen, J.B. Nielsen, K. Schønning, Y. Agers $\varnothing$, and L. Guardabassi. 2016. Hostspecific patterns of genetic diversity among IncI1-I $\gamma$ and IncK plasmids encoding CMY-2 $\beta$-lactamase in Escherichia coli isolates from humans, poultry meat, poultry, and dogs in Denmark. Appl. Environ. Microbiol. 82:4705-4714.

29. Mo, S.S., M. Sunde, H.K. Ilag, S. Langsrud, and E. Heir. 2017. Transfer potential of plasmids conferring extendedspectrum-cephalosporin resistance in Escherichia coli from poultry. Appl. Environ. Microbiol. 83:e00654-17.

30. Lemire, J.A., J.J. Harrison, and R.J. Turner. 2013. Antimicrobial activity of metals: mechanisms, molecular targets and applications. Nat. Rev. Microbiol. 11:371-384.

31. Pal, C., J. Bengtsson-Palme, E. Kristiansson, and D.G.J. Larsson. 2015. Co-occurrence of resistance genes to antibiotics, biocides and metals reveals novel insights into their co-selection potential. BMC Genomics 16:964.

32. Yazdankhah, S., K. Rudi, and A. Bernhoft. 2014. Zinc and copper in animal feed-development of resistance and coresistance to antimicrobial agents in bacteria of animal origin. Microb. Ecol. Health Dis. 25. DOI: 10.3402/mehd .v25.25862.

33. Chen, S., X. Li, G. Sun, Y. Zhang, J. Su, and J. Ye. 2015. Heavy metal induced antibiotic resistance in bacterium LSJC7. Int. J. Mol. Sci. 16:23390-23404.

34. Hobman, J.L., and L.C. Crossman. 2015. Bacterial antimicrobial metal ion resistance. J. Med. Microbiol. 64(Pt 5): 471-497. 
35. Osredkkar, J.S.N. 2011. Copper and zinc, biological role and significance for copper/zinc imbalance. J. Clin. Toxicol. S3.

36. Monteiro, S.C., S. Lofts, and A.B. Boxall. 2010. Preassenmental impact of zinc and copper used in animal nutrition. Scientific/technical report submitted to EFSA. 7(9) ed. EFSA Supporting Publications. https://doi.org/10 .2903/sp.efsa.2010.EN-74 (accessed January 13, 2020).

37. McBride, M.B., and G. Spiers. 2001. Trace element content of selected fertilizers and dairy manures as determined by ICP-MS. Commun. Soil Sci. Plant Anal. 32:139-156.

38. Debski, B. 2016. Supplementation of pigs diet with zinc and copper as alternative to conventional antimicrobials. Pol. J. Vet. Sci. 19:917-924.

39. Jensen, J., M.M. Larsen, and J. Bak. 2016. National monitoring study in Denmark finds increased and critical levels of copper and zinc in arable soils fertilized with pig slurry. Environ. Pollut. 214:334-340.

40. Heo, J.M., F.O. Opapeju, J.R. Pluske, J.C. Kim, D.J. Hampson, and C.M. Nyachoti. 2013. Gastrointestinal health and function in weaned pigs: a review of feeding strategies to control post-weaning diarrhoea without using in-feed antimicrobial compounds. J. Anim. Physiol. Anim. Nutr (Berl). 97:207-237.

41. Neethu, C.S., K.M. Mujeeb Rahiman, A.V. Saramma, and A.A. Mohamed Hatha. 2015. Heavy-metal resistance in Gram-negative bacteria isolated from Kongsfjord, Arctic. Can. J. Microbiol. 61:429-435.

42. Mo, S.S., J.S. Slettemeas, E.S. Berg, M. Norstrom, and M. Sunde. 2016. Plasmid and host strain characteristics of Escherichia coli resistant to extended-spectrum cephalosporins in the Norwegian broiler production. PLoS One. 11: e0154019.

43. Denisuik, A.J., P.R. Lagace-Wiens, J.D. Pitout, M.R. Mulvey, P.J. Simner, F. Tailor, J.A. Karlowsky, D.J. Hoban, H.J. Adam, and G.G. Zhanel. 2013. Molecular epidemiology of extended-spectrum beta-lactamase-, AmpC beta-lactamase- and carbapenemase-producing Escherichia coli and Klebsiella pneumoniae isolated from Canadian hospitals over a 5 year period: CANWARD 2007-11. J. Antimicrob. Chemother. 68(Suppl 1):i57-i65.

44. Wiegand, I., K. Hilpert, and R.E. Hancock. 2008. Agar and broth dilution methods to determine the minimal inhibitory concentration (MIC) of antimicrobial substances. Nat. Protoc. 3:163-175.

45. Sunde, M., and H. Sorum. 2001. Self-transmissible multidrug resistance plasmids in Escherichia coli of the normal intestinal flora of healthy swine. Microb. Drug Resist. 7: 191-196.

46. McFarland, J. 1907. The nephelometer: an instrument for estimating the number of bacteria in suspensions used for calculating the opsonic index and for vaccines. J Am Med Assoc. XLIX:1176-1178.

47. Perez-Perez, F.J., and N.D. Hanson. 2002. Detection of plasmid-mediated AmpC beta-lactamase genes in clinical isolates by using multiplex PCR. J. Clin. Microbiol. 40: 2153-2162.

48. Hernandez-Ramirez, K.C., V.M. Chavez-Jacobo, M.I. Valle-Maldonado, J.A. Patino-Medina, S.P. Diaz-Perez, I.E. Jacome-Galarza, R. Ortiz-Alvarado, V. Meza-Carmen, and M.I. Ramirez-Diaz. 2017. Plasmid pUM505 encodes a Toxin-Antitoxin system conferring plasmid stability and increased Pseudomonas aeruginosa virulence. Microb. Pathog. 112:259-268.
49. Di Luca, M.C., V. Sorum, I. Starikova, J. Kloos, N. Hulter, U. Naseer, P.J. Johnsen, and O. Samuelsen. 2017. Low biological cost of carbapenemase-encoding plasmids following transfer from Klebsiella pneumoniae to Escherichia coli. J. Antimicrob. Chemother. 72:85-89.

50. Ou, J.T. 1973. Effect of $\mathrm{Zn} 2+$ on bacterial conjugation: increase in ability of $\mathrm{F}^{-}$cells to form mating pairs. J. Bacteriol. 1973:648-654.

51. Bednorz, C., K. Oelgeschlager, B. Kinnemann, S. Hartmann, K. Neumann, R. Pieper, A. Bethe, T. Semmler, K. Tedin, P. Schierack, L.H. Wieler, and S. Guenther. 2013. The broader context of antibiotic resistance: zinc feed supplementation of piglets increases the proportion of multi-resistant Escherichia coli in vivo. Int. J. Med Microbiol. 303:396-403.

52. Zhang, Y., A.Z. Gu, T. Cen, X. Li, M. He, D. Li, and J. Chen. 2018. Sub-inhibitory concentrations of heavy metals facilitate the horizontal transfer of plasmid-mediated antibiotic resistance genes in water environment. Environ. Pollut. 237:74-82.

53. Beaber, J.W., B. Hochhut, and M.K. Waldor. 2004. SOS response promotes horizontal dissemination of antibiotic resistance genes. Nature 427:72-74.

54. Klümper, U., A. Dechesne, L. Riber, K.K. Brandt, A. Gulay, S.J. Sorensen, and B.F. Smets. 2017. Metal stressors consistently modulate bacterial conjugal plasmid uptake potential in a phylogenetically conserved manner. ISME J. 11:152-165.

55. Suzuki, S., M. Kimura, T. Agusa, and H.M. Rahman. 2012. Vanadium accelerates horizontal transfer of tet(M) gene from marine Photobacterium to Escherichia coli. FEMS Microbiol. Lett. 336:52-56.

56. Crane, J.K., M.B. Cheema, M.A. Olyer, and M.D. Sutton. 2018. Zinc blockade of SOS response inhibits horizontal transfer of antibiotic resistance genes in enteric bacteria. Front. Cell. Infect. Microbiol. 8:410.

57. Saliu, E.M., M. Eitinger, J. Zentek, and W. Vahjen. 2019. Nutrition related stress factors reduce the transfer of extended-spectrum beta-lactamase resistance genes between an Escherichia coli donor and a Salmonella Typhimurium recipient in vitro. Biomolecules 9:pii: E324.

58. Parra, B., G.R. Tortella, S. Cuozzo, and M. Martinez. 2019. Negative effect of copper nanoparticles on the conjugation frequency of conjugative catabolic plasmids. Ecotoxicol. Environ. Saf. 169:662-668.

59. Baker-Austin, C., M.S. Wright, R. Stepanauskas, and J.V. McArthur. 2006. Co-selection of antibiotic and metal resistance. Trends Microbiol. 14:176-182.

60. Pérez-Mendoza, D., and F de la Cruz. 2009. Escherichia coli genes affecting recipient ability in plasmid conjugation: are there any? BMC Genomics 10:71.

61. Furuya, N., and T. Komano. 2000. Initiation and termination of DNA transfer during conjugation of IncI1 plasmid R64: roles of two sets of inverted repeat sequences within oriT in termination of R64 transfer. J. Bacteriol. 182:3191-3196.

Address correspondence to: Ingun Lund Wits $\phi, P h D$ Department of Paraclinical Sciences Faculty of Veterinary Medicine Norwegian University of Life Sciences Ullevålsveien 72 Oslo 0454 Norway

E-mail: ingun.lund.witso@nmbu.no 